powerful W.N.W. channels of mineralization in the district, with a yield so far of 460,000 tons of fluorspar and 48,000 tons of galena. The collar of the boring is also $500 \mathrm{ft}$. from the hanging wall of the E.N.E. Boltsburn Vein, a weak but very persistent fracture, which has yielded 143,000 tons of galena, mainly from associated replacements. Both veins dip towards the boring, which was sited so as to pass through them at depth. Below the Great Limestone, the base of which is taken as the Viséan-Namurian boundary in northern England, a normal Middle Limestone Group succession was encountered. Two quartz-dolerite sills were proved in these beds; the Little Whin Sill, $6 \mathrm{ft}$. thick, is intruded into the Three Yard Limestone, and the Great Whin Sill, $200 \mathrm{ft}$. thick, lies beneath the Jew Limestone. The base of the Middle Limestone Group remains to be defined exactly when the faunal study of the cores has been carried out, but the expected change from dark blue-grey limestone to pale grey limestone shows the approximate position of this boundary. The Lower Limestone Group is represented by an alternation of light grey limestones, shales and sandstones; no massive Melmerby Scar Limestone such as is present below Cross Fell is developed; but the typical 'pseudo-breccia' lithology characteristic of this limestone is present in some of the bands. Beneath these light-coloured limestones, black shale with very thin quartz- and feldspar-bearing conglomerate beds rest directly on weathered granite which in a few feet gives place to fresh, well-foliated microcline-quartz-muscovite-oligoclase rock. The foliation is nearly horizontal, and aplite and pegmatite bands occur at various angles.

So far, ten intersections of metalliferous mineralization have been made. Of eight in the Carboniferous, three are horizontal replacements in limestone and one of these is $16 \mathrm{ft}$. thick, rich in green fluorite and sphalerite. Two typical Pennine Zone I veins, carrying pyrrhotite, fluorite, quartz, have been intersected within the granite at $1,349-1,363 \mathrm{ft}$. and at 1,585-1,656 ft., the latter being accompanied by extreme alteration of the granite.

Two definite conclusions may be drawn at this stage: (1) the granite so far proved is of pre-Carboniferous age; (2) the mineral veins were fed from some source beneath that part of the granite so far drilled. To these may be added the suggestion that the buried pre-Carboniferous cupolas served to localize the upward flow of mineralizing fluids into the Carboniferous rocks.
K. C. Dunham
G. A. L. Johnson
M. H. P. Вoтt
B. L. HoDGE

Department of Geology,

University Science Laboratories, South Road, Durham.

1 Dunham, K. C., Quart. J. Geol. Soc., 90, 689 (1934).

2 Dunham, K. C., "Geology of the Northern Pennine Prefield", Mem Geol. Survey" (1948).

${ }^{3}$ Bott, M. H. P., and Masson-Smith, D., Geol. Mag., 90, 127 (1953) Quart, J. Geol. Soc., 113,93 (1957).

Hospers, J., and Willmore, P. L., Geol. Mag., 90, 117 (1953).

${ }^{5}$ Bott, M. P. H., Geol. Mag., 97, 511 (1960).

\section{Isotopic Ages of the Weardale Granite}

AGE determinations have been carried out on muscovite from the Weardale Granite ${ }^{1}$ by both the rubidium-strontium and potassium-argon methods. One specimen from a depth of $1,396 \mathrm{ft}$. in the borehole was measured by both methods, while another from
$1,314 \mathrm{ft}$. was measured by the potassium-argon method only.

Isotopic dilution techniques were employed for the determination of rubidium, strontium and argon. A flame photometric method was employed to determine potassium. The results for the rubidiumstrontium method are given in Table 1 , and those for the potassium-argon method in Table 2.

\begin{tabular}{|c|c|c|c|c|}
\hline $\begin{array}{l}\text { Depth of sample } \\
\text { (ft.) }\end{array}$ & $\begin{array}{l}\text { Rubidium } \\
\text { (p.p.m.) }\end{array}$ & $\begin{array}{c}\text { Normal } \\
\text { strontium } \\
\text { (p.p.m.) }\end{array}$ & $\begin{array}{c}\text { Radiogenic } \\
\text { strontium } \\
\text { (p.p.m.) }\end{array}$ & Age (m.yr.) \\
\hline $\begin{array}{l}1,396 \\
1,396\end{array}$ & $\begin{array}{l}763 \\
757\end{array}$ & $\begin{array}{l}19 \cdot 4 \\
19 \cdot 6\end{array}$ & $\begin{array}{l}1 \cdot 15 \\
1 \cdot 15\end{array}$ & $\begin{array}{l}360 \pm 12 \\
365 \pm 12\end{array}$ \\
\hline
\end{tabular}

Table 2. Potassium-Argon Derterminations on Muscovite

$$
\begin{aligned}
& \begin{array}{ccccc}
\begin{array}{c}
\text { Depth of } \\
\text { sample }
\end{array} & \begin{array}{l}
\mathbf{K}_{\mathbf{g}} \mathrm{O} \\
\text { (per }
\end{array} & \begin{array}{l}
\text { Weight Radiogenic Atmospheric } \\
\text { fused }
\end{array} & \begin{array}{c}
\text { argon } \\
\text { argon }
\end{array} & \text { Age (m.yr.) }
\end{array} \\
& \begin{array}{cccccc}
\begin{array}{c}
\text { sample } \\
\text { (ft.) }
\end{array} & \begin{array}{c}
\text { (per } \\
\text { cent) }
\end{array} & \begin{array}{c}
\text { fused } \\
\text { (gm.) }
\end{array} & \begin{array}{c}
\text { argon } \\
\text { (p.p.m.) }
\end{array} & \begin{array}{c}
\text { argon } \\
\text { (per cent) }
\end{array} & \text { Age (m.yr.) } \\
\mathbf{1 , 3 9 6} & \mathbf{1 0 \cdot 0 1} & 2 \cdot 034 & 0 \cdot 240 & 17 \cdot 4 & 370 \pm 10 \\
\mathbf{1 , 3 1 4} & \mathbf{1 0 \cdot 2 6} & \mathbf{3 \cdot 2 9 1} & \mathbf{0 . 2 3 9} & \mathbf{2 4} & \mathbf{3 5 6} \pm \mathbf{1 2}
\end{array} \\
& \text { Decay constants of potassium-40: } \lambda \mathrm{k}=0.584 \times 10^{-10} \mathrm{yr}^{-1}
\end{aligned}
$$

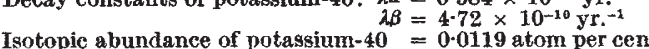

$$
\begin{aligned}
& \text { * Potassium analyses by Dr. N. J. Snelling. }
\end{aligned}
$$

All the results agree within the limits of error. Agreement between the two methods makes it highly probable that the weighted mean of the four figures is close to the true age of emplacement of the granite.

The following points may be noted : (i) The weighted mean of $362 \pm 6$ million years corresponds to a Middle or Late Devonian age of emplacement, according to the latest time-scales ${ }^{2,3}$. The isotopic results therefore agree with the borehole evidence for the pre-Carboniferous age of the granite. (ii) The age of the Northern Pennine mineralization from the field evidence ${ }^{4}$ is undoubtedly post-Carboniferous and probably pre-Tertiary. From lead isotope measurements by Moorbath ${ }^{5}$ the mean model age of Northern Pennine galenas is $280 \pm 30$ million years, indicating that the mineralization is in fact of Hercynian age. Thus, from the lead isotope data and the absolute ages, as well as from the observations re. ported in the preceding communication, the northern Pennine mineralization is not connected with the emplacement of the Weardale granite. (iii) The weighted mean of $362 \pm 6$ million years for the Weardale granite is significantly younger than the dates for the Shap granite given by Kulp et al. ${ }^{6}$. These authors obtained $391 \pm 7$ million years by the potassium-argon method and $381 \pm 7$ million years by the rubidium-strontium method. Unpublished rubidium-strontium results obtained at Oxford on the Skiddaw granite suggest that the latter may be contemporaneous with the Weardale granite.

We are indebted to Prof. Dunham for supplying the material for this investigation.

\section{H. DODSON}

S. MoORBATH

Department of Geology and Mineralogy,

University Museum, Oxford.

1 Dunham, K. C., Bott, M. H. P., Johnson, G. A. L., and Hodge, B. L. (preceding communication)

${ }^{2}$ Holmes, A., Trans. Edin. Geol. Soc., 17, 183 (1960).

${ }^{3}$ Kulp, J. L., Rep. Twenty-first Session Internat. Geol. Congress, Part III, 18 (1960).

4 Dunham. K. C., Trans. Geol. Soc. Glasgow, 21, Part III, 396 (1952).

${ }^{5}$ Moorbath, S., Nature, 188, 595 (1959). Kulp, J. I. , Long, L. E., Giffin, C. F., Mills, A. A., Lambert, R. St. J.,
Giletti, B. J., and Webster, R. K., Nature, 185, 495 (1960). 